\title{
血友病と線溶系
}

野上恵嗣*, 中島由翔

\section{Hemophilia and fibrinolysis system}

Keiji Nogami, Yuto NaKaJima

要約：血液凝固第 VIII 因子欠乏症の血友病 A は, 細胞基盤型凝固機序により生じるトロンビン生成が著明に低 下し, フィブリン生成も極めて少なくかつ不安定で重篤な出血を呈する. 従来の血液凝固研究は, 内因系 / 外 因系／抗凝固系／線溶系の個々の反応系は十分に研究され発展した。しかし凝固過程中, これら複数系が巧み に絡み合って進行していく概念が近年支持されている，凝固と線溶は巧妙にバランスをとりながら恒常性の維 持を保っている．特に第VIII 因子が両反応系のクロストークポイントの一つであることが明らかとなり，さら に血友病の病態に第 VIII 因子以外にトロンビン活性化線溶阻害因子の関与も近年注目されている。この病態解 明に包括的に凝固線溶動態を評価できる測定法も近年発展してきた，近い将来，凝固系-線溶系制御軸を中心と した患者個々の重症度の予測や止血管理の方針, 長期にわたる止血方針を立案することが可能になるかもしれ ない.

Key words: factor VIII, hemophilia, plasmin, thrombin activatable fibrinolysis inhibitor, global assay

\section{緒言}

血液凝固反応機序は Hoffman $ら^{1)}$ が提唱した cellbased coagulation model theory が現在支持されてい る. 活性型第(F) VII 因子（FVIIa）が出血部位に露 出される組織因子と複合体を形成し, FXを活性化し て微量のトロンビンが生成される(初期相)。このト ロンビン量では充分なフィブリン形成に至らず止血 機能は不充分であるが, 同時に血小板およびFVIII やFVを活性化する。これにより活性化血小板上で 凝固因子の活性化が連鎖的に起こりトロンビン生成 は増大する (増幅・増大相)。このトロンビンバース トにより thrombin activatable fibrinolysis inhibitor （TAFI）を介した線溶抵抗性の安定フィブリンが形 成される ${ }^{2)}$. 活性化 FVIIIa は FIXaの補因子として内 因系 FXa 反応系の FXa生成反応速度を著明に増加

*責任者連絡先：

奈良県立医科大学小児科

干 634-8522 奈良県橿原市四条町 840

Tel: 0744-29-8881, Fax: 0744-24-9222

E-mail: roc-noga@naramed-u.ac.jp
させる.よって, FVIII 欠乏症の血友病 A では, ト ロンビン生成が著明に低下し，フィブリン生成も極 めて少なくかつ不安定で重篤な出血を呈する. F8 遺 伝子の cDNA が 1984 年にクローニングされ, 以後 FVIII 分子の機能構造解析は著しい発展を遂げ, 同時 に血友病 Aの詳細な病態解明と治療にも貢献して きた ${ }^{3)}$. 一方, 従来の血液凝固研究は, 内因系 $/$ 外 因系／抗凝固系／線溶系に分けられ, 個々の系につ いて十分に研究され現在まで発展してきた。しかし ながら, 凝固過程中ではこれら複数系が巧みに絡み 合って進行していく概念が近年支持されてきている が，未だ解明されていないことが多い，最近，FVIII 欠乏病態の血友病と線溶系との関連性が特に注目さ れてきた. 本稿では FVIII 分子と線溶系制御の関係, 血友病と線溶系との関連について最近の知見も含め 述べる。

\section{FVIII-線溶系制御}

1）FVIII/FVIIIa の機能構造 3,4)

FVIII はアミノ酸組成の相同性より A1-A2-B-A3- 


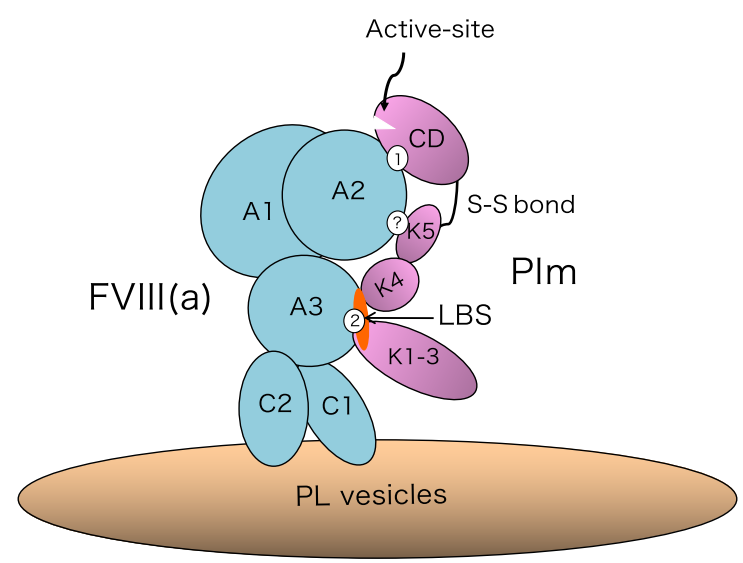

困 1 FVIII-Plasmin 相互作用の結合モデル ${ }^{9)}$

(1)と(2)は結合部位を示す. LBS ; リジン結合部位, K ; Kringle domain, PL ; リン脂質膜, Plm ; Plasmin

C1-C2 のドメイン構造を呈する. 循環血漿中, A1A2-B ドメインの重鎖 $(90$ ～ $210 \mathrm{kDa})$ と, A3-C1-C2 ドメインの軽鎖 $(80 \mathrm{kDa})$ の heterodimer として存在 し, von Willebrand 因子と複合体を形成している。 FVIII はトロンビンやFXaにより, 重鎖 $\mathrm{Arg}^{372}$, $\mathrm{Arg}^{740}$ と軽鎖 $\mathrm{Arg}^{1689}$ で開裂し, 重鎖は 50-kDa A1 と 40-kDa A2 ドメイン, 軽鎖は $70 \mathrm{kDa} \mathrm{A} 3-\mathrm{C} 1-\mathrm{C} 2$ ドメイ ンに分解され，FVIIIa heterotrimerとなる，FVIIIaは FIXa 惹起 FX 活性化の凝固反応速度を約 $10^{6}$ 倍増強 する，FVIIIaに一旦活性化されると，容易にA2 ド メインが解離して FVIIIa が不活化され，さらに活性 型プロテイン $\mathrm{C} /$ プロテイン S (APC/PS) や FXaのセ リンプロテアーゼが $\mathrm{Arg}^{336}, \mathrm{Arg}^{562}, \mathrm{Lys}^{36}$ で分解し, 完全に失活させる ${ }^{3-5)}$. APC/PS 惹起 FVIIIa不活化機 序に FVがその補因子として作用し，不活化をさら に増強させる ${ }^{3-5)}$. 本邦で欧米人に存在する $\mathrm{FV}_{\text {Leiden }}$ （R506Q）以外で FV 変異による APCレジスタンスに よる重篤な血栓症を呈する症例（FV Nara; R1920W） が初めて発見された ${ }^{6}$. このように幾つもの凝固因 子による FVIII 制御機序により, FVIII(a) 活性化と不 活化のバランスを絶妙に制御することにより，易出 血または過凝固を防いでいる.

\section{2) プラスミン-FVIII 関連制御}

In vitro 純化系において, プラスミノゲンから活性 化された極少量のプラスミン (Plm) でさえ, FVIII を反応初期相において急峻に活性化し, その後急速 に不活化する。 その際, Plm は FVIII 分子内の 6 部位
を sequential に限定分解 $\left(\mathrm{Lys}^{36}, \mathrm{Arg}^{336}, \mathrm{Arg}^{372}, \mathrm{Arg}^{740}\right.$, $\left.\mathrm{Arg}^{1689}, \mathrm{Arg}^{1721}\right)$ するが, 同部位を開裂する FXaや APC に比し FVIII 活性化および不活化はより急峻で ある ${ }^{7)}$. この活性化・不活化機序は von Willebrand 因 子やリン脂質膜の存在には全く影響されない. Plm は分子上のリジン結合部位（LBS）を介してフィブ リンをはじめ多くの凝固蛋白と相互作用をなす。し かし, FVIII-Plm 相互作用において, FVIIIの A2 ド メインと Plm の活性化ドメインは LBS を介さず (非 依存性）結合することにより $\mathrm{Arg}^{336}, \mathrm{Arg}^{372}$ や $\mathrm{Arg}^{740}$ を開裂させ，FVIII 活性化および不活化を制御す る ${ }^{8,9)}$. 一方, FVIII の A3 ドメインは Plm の Kringle 1-3 ドメインと LBS を介して結合して Lys ${ }^{36}$ を開裂さ せることにより不活化制御している ${ }^{9,10)}$ 。そして, FVIII-PIm 相互作用は tenase 複合体では FIXaにより 制御されている。.以上から, Plmが FVIII を凝固初期 相で活性化／不活化する FVIII-Plm 制御軸において, その結合反応様式を初めてモデリングすることがで きた（図 1)。元来, Plm は線溶能のみならず, 向凝 固能も有することは報告されていたが，これは Plm による直接的な FVIII 活性化が寄与する事も明らか になったささらに全血や血漿を用いた，より生理的 機能を反映しうる包括的凝固機能の評価においても, FVIII-Plm 制御軸における向凝固能が観察されてい $3^{11)}$. 


\section{2. 血友病と線溶系}

血液凝固反応により生成されたトロンビンは, 最 終的にフィブリン塊を形成して止血を完了させる. その後, 形成されたフィブリンは, Plmによる線溶 作用によって分解・除去される ${ }^{12)}$. Plmによる線溶 機構は，フィブリンの Plmによる部分加水分解によ り，フィブリン分子上に出現する $\mathrm{C}$ 末端のリジン残 基を介してプラスミノゲンや Plm, 組織型プラスミ ノゲン活性化因子（tPA）が結合することにより効率 よく展開される.

\section{1）トラネキサム酸（TXA）}

TXA は,リジンと類似した構造を有する線溶阻害 剤である. TXA はプラスミノゲンのリジン結合部位 を介して，フィブリンへの吸着を阻止することで抗 線溶作用を発揮し, 血友病患者における粘膜出血へ の止血に対して現在まで臨床の場で多数使用されて きた。最近，TXAの血友病に対する臨床効果におけ る更なる新しい知見が報告されている。T Tran ら ${ }^{13)}$ は, インヒビター保有血友病 A 患者に TXA とバイ パス止血製剂の遺伝子組換え型 FVII 製剤または活 性型プロトロンビン複合体製剤との併用療法で治療 し, rotational thromboelastometry（ROTEM）を用い て包括的に凝固能を評価したところ，バイパス止血 製剂単独療法よりTXA との併用療法のほうが有効 であり，血栓症や凝固促進を示唆する様な所見は認 めなかったと報告している。また Janbain ら ${ }^{14)}$ は, FVIII ノックアウトマウス（FVIII-KO）を用いて， FVIII 単独と FVIII+TXA の併用療法における凝固能 をトロンビン生成能で評価し, 形成したフィブリン を走査型電子顕微鏡での解析にて比較した。 トロン ビン生成試験では TXA との併用効果は有意差を認 めなかったが, 走査型電子顕微鏡での観察では, FVIII+TXA 併用療法の方がより強力なフィブリン網 を形成していることが示唆された。また，FVIII-KO マウスに対して外的な膝関節出血を施し, FVIII 単独 と FVIII+TXA の併用療法の治療効果を MRI 画像で 比較したところ, TXA を併用したマウスは関節出血 を有意に減少させていた。これらの結果は，TXA と FVIII 製剤，もしくは TXA とバイパス止血製郕の併 用療法が血友病患者の治療としての一助になる可能
性があるといえよう。

\section{2) TAFI}

TAFI は凝固系と線溶系の両者に関与する線溶抑 制因子である ${ }^{2)}$. TAFIはトロンビンにより活性化さ れ，活性化 TAFI（TAFIa）に変換される. TAFIaは フィブリンの C 末端リジン残基を除去することによ り, 線溶系酵素のフィブリンへの結合を阻害するこ とにより線溶反応を抑制する. TAFIの濃度が一定以 下になればフィブリン上の C 末端のリジン残基数が 多くなり, Plm 生成を促進し, 線溶反応が充進する. 近年, 血友病 A 患者における TAFI の関連性が特に 注目されている. Wyseureら ${ }^{15)}$ の報告では, 抗 FVIII 抗体投与による後天性血友病 A モデルマウス, TAFI を欠損させた後天性血友病 $\mathrm{A}$ モデルマウス, 先天性 血友病 $\mathrm{A}$ モデルマウスを用いて関節障害を施したと ころ, TAFI 欠損の後天性血友病 A マウスと先天性血 友病 $\mathrm{A}$ マウスは重度の関節出血を認めたが, 後天性 血友病 A モデルマウスは顕著に軽症であった。ま た，循環血中 TAFI 活性を測定したところ，先天性 血友病 A マウスでは TAFI の活性化は認められな かったが, 後天性血友病 A マウスでは顕著な TAFI の活性化を認めた. 先天性血友病 A マウスでは TAFI が著しく欠損している事により関節出血が悪化した ことを示唆しており, 血友病性関節出血における TAFIの重要な関与を示唆した。

同グループ 16) は，さらに血友病患者は TAFI 活性 の減少が異常な血管リモデリングを引き起こすとい う仮説のもと, 関節出血後の血管リモデリングにお ける FVIII およびTAFIの関与について検討した。後 天性血友病 A マウスに抗 TAFI 抗体を投与し関節障 害を施したところ，過度の血管リモデリングと血管 拡大が持続した。 また，血友病 A マウスにおける TAFI の過剩発現は, 異常な血管の拡大と血管漏出を 防止することが明らかになった。これらの結果より， 血友病患者における TAFI 欠乏では, 関節出血後の 不適応な血管リモデリングが引き起こされることが 示唆された。

Semeraro ら ${ }^{17)}$ は, オンデマンドで治療された重 症血友病 $\mathrm{A}$ の患者 61 人を年間出血回数で軽症, 中 等症, 重症に分類し, 血栓溶解時間, TAFI 活性, 精 製 TAFIa の添加時の線溶時間の延長としての TAFIa 
(A)

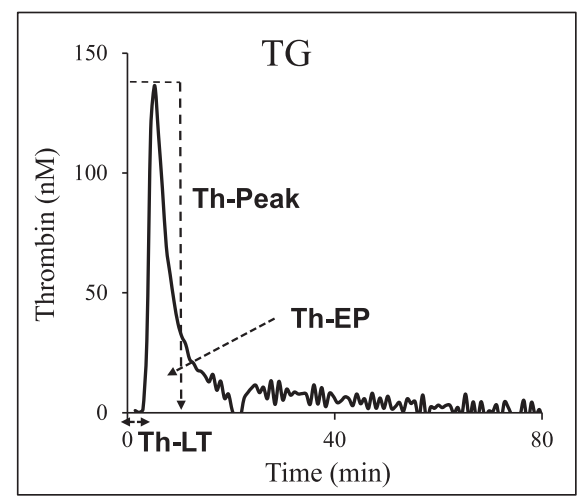

(B)

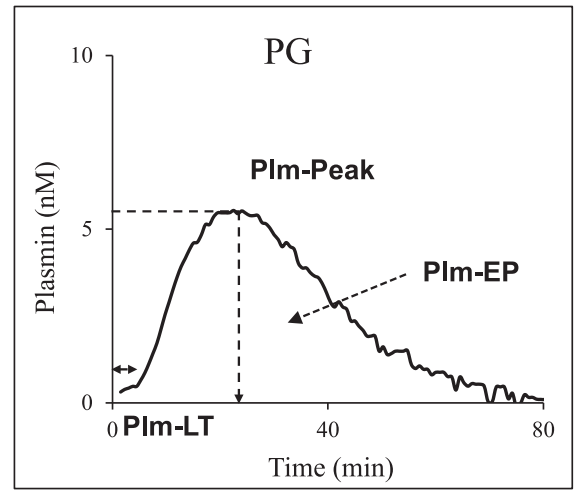

図 2 正常血漿に拈けるトロンビン・プラスミン生成試験（T/P-GA）

正常血漿から得られるトロンビン生成波形（TG）（A）とプラスミン生成波形（PG）（B）とそのパラメータを示す．Th: thrombin, Plm; plasmin, LT; lag time, Peak; peak level, EP; endogenous potential.

への反応性, さらに血中 TAFIa/ai 濃度測定について 解析を行った。 その結果, 血友病患者は健常者と比 較すると，TAFIa/ai 濃度は同程度であったが，血栓 溶解時間が短く, TAFIaの生成量は少なく, TAFIa への反応性も低下していた，血栓溶解時間は, 軽度, 中等度, 重度の血友病患者では差を認めなかったが, 出血傾向が重篤になるに従い TAFIa の生成量と TAFIaへの反応性は低下した。血友病 A 患者におけ る TAFI 経路の損傷度が出血傾向と相関することか ら, TAFI 検査が血友病 A 患者の出血傾向を予測する ために有用であることも報告されており, 今後の臨 床応用へのさらなる発展が期待される。

\section{3. 血友病における包括的凝固線溶解析}

正常な止血反応では, 凝固反応と線溶反応の両者 が適度なバランスを維持することで行われている。 したがって, 両者のバランスが均衡状態なのか不均 衡状態なのか, すなわち凝固線溶能を同時に測定す ることにより, 全体的な止血能を評価することが可能 と考えられる. 最近我々は, 従来から包括的凝固機 能検査として用いられていたトロンビン生成試験お よび凝固波形解析をさらに発展させた, トロンビン. プラスミン生成試験（Thrombin/Plasmin-Generation Assay: T/P-GA) と凝固線溶波形解析 (Clot Fibrinolysis Waveform Analysis: CFWA）の開発に成功した. 以下
に概説する。

\section{1） T/P-GA（図 2) ${ }^{18)}$}

血漿検体へのトリガー試薬として, 従来のトロン ビン生成試験（Thrombin generation assay: TGA）のト リガー試薬である組織因子／リン脂質に加えて組織 プラスミノーゲンアクチベータ（t-PA）を添加し, 生成されたトロンビンと Plm を各々の蛍光発色基質 を用いて検出することで潜在的な凝固線溶能を同時 に包括的に評価できる T/P-GAを確立した。 T/P-GA は, トロンビンと Plmの生成量を, 反応の開始時間で ある Lag time, ピーク值 (Peak thrombin or plasmin), ピークに達する時間（time to peak）, 総生成量（Endogenous potential of thrombin or plasmin) などのパラ メー夕を算出して定量的に凝固線溶動態を評価で きる。

我々は, T/P-GA を用いて各凝固因子欠乏症の凝固 線溶能を評価したところ, FV, FX 欠乏症はトロンビ ン, Plm 生成量が共に低下するが，フィブリノゲン 欠乏症やプラスミノゲン欠そ症は, トロンビン生成 量は正常であるが, Plm生成量が低下してした。先 天性血友病 A 20 例を T/P-GA で評価したところ, ト ロンビン生成量は低下していたが Plm 生成量は正常 血漿とほぼ同等であり, 血友病 $\mathrm{A}$ 患者は凝固能と線 溶能の不均衡が生じていることが明らかになった ${ }^{18)}$. 最近, 我々は後天的に重篤な出血をきたす後天性血 友病 $\mathrm{A}$ 患者のモニタリングにも T/P-GA が有用であ 
(A)

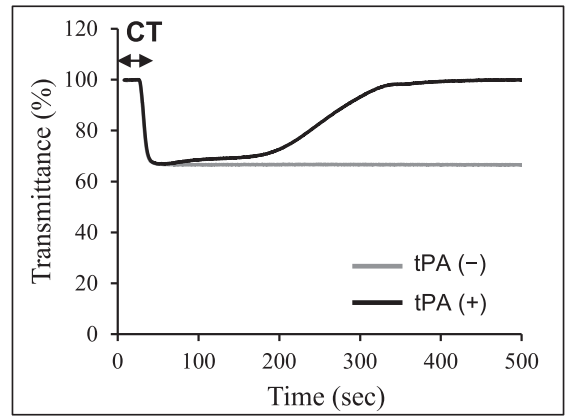

(B)

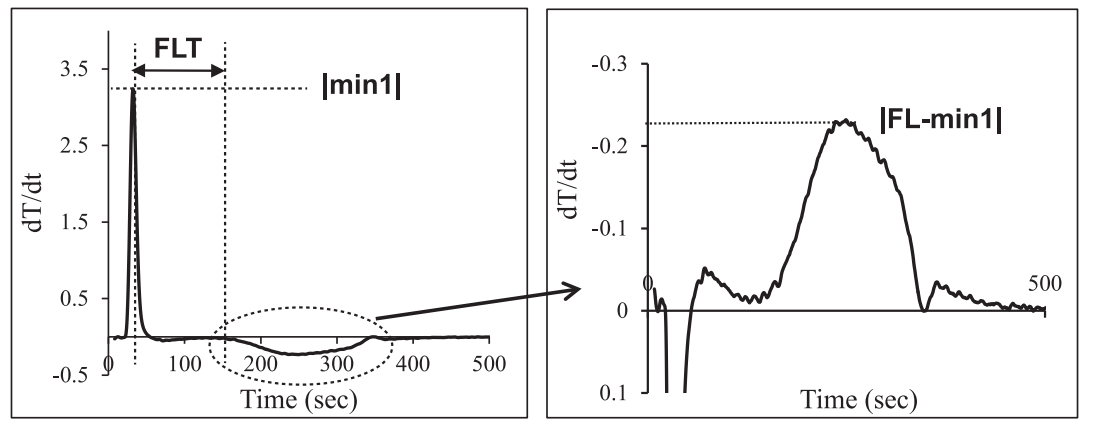

困 3 正常血漿における凝固線溶波形解析 (CFWA)

正常血漿から得られる tPA 非存在下抢よび存在下の凝固線溶波形（A）とそのパラメータを示す.（B）（A）の一次微分波 形, （C）（B）の線溶部分の逆波形を示す. tPA; tissue-type plasminogen activator, CT; clot time, FLT; fibrinolysis lag time, |min1|; maximum coagulation velocity, FL-|min1|; maximum fibrinolysis velocity

ることを報告した ${ }^{19)}$. 後天性血友病 $\mathrm{A}$ 患者の重篤な 出血症状時はトロンビン生成だけでなく Plm 生成も 極めて低下しており，トロンビンょり Plm生成の方 が早期に回復し, Plm 生成が患者の臨床症状の評価 に有用であることが示唆された。

\section{2) CFWA (図 3) ${ }^{20)}$}

凝固波形解析（Clot waveform analysis; CWA）は, 透過光分析による自動凝固分析装置を用いて, フィ ブリン形成過程における血漿サンプルの透過度の変 化を検出し, 包括的凝固能を評価できる. 我々は最 近, $\mathrm{APTT}$ の $\mathrm{CaCl}_{2}$ 添加時に $\mathrm{tPA}$ を同時に添加するこ とによりCFWA を用いて凝固線溶動態を同時に評価 できる測定法を確立した。CFWAでは，凝固相は凝 固時間 (Clot time: CT), 凝固波形を一次微分して凝 固速度を算出し, その最大值である最大凝固速度 (|min1 $\mid)$ で解析し, 線溶相は CT から溶解開始まで の時間 (Fibrinolysis lag time: FLT), 線溶波形を一次 微分して線溶速度を算出し, その最大值である最大 線溶速度 (FL-|min1|), 線溶反応総量 (Endogenous fibrinolysis potential: EFP) により定量的に解析で きる。

本測定法を用いて, 正常血漿に様々な濃度のアル ガトロバン (トロンビン阻害剤), TXA, トロンボ モデュリンを添加し, 凝固線溶動態を検討した。ア ルガトロバンを添加した場合, 濃度依存性に CT が 延長し|min1|は低下した。 さらに, CT延長に伴って FLT も延長し, 線溶開始が遅延していた. TXAの存
在下では，凝固相に影響は与えなかったが，濃度依 存性に FLT の延長と FL-| $\min 1 \mid$ の低下を認めた。低濃 度のトロンボモデュリンを添加した血漿では, 凝固 相に影響を与えなかったが, FL- $|\min 1|$ の低下を認め た。高濃度のトロンボモデュリンでは, 凝固相も線 溶相も阻害した。これらの結果は本測定法が凝固能 と線溶能の相互作用（interplay）を反映できている ことも示された ${ }^{20)}$.

FVIII 欠乏血漿を CFWA で解析すると, 凝固相は 正常血漿より延長し, 線溶相はフィブリン形成前に 開始していることが明らかになった ${ }^{20)}$. FL-|min1|は 正常血漿とほほ同等であったが, 二峰性の線溶波形 を示し，EFPは著明に増加していた。この結果も， 血友病 A が凝固系と線溶系が不均衡であることを示 していたＦVIII 欠乏血漿またはFIX 久乏血漿に様々 な濃度の FVIII 製剤, FIX 製剤をそれぞれ添加して CFWA を用いて解析すると, 両者共に, 凝固相にお ける CT と $|\min 1|$ は濃度依存性に改善した。線溶相 は, 低濃度の FVIII（<1 IU/dL）の場合は改善効果 を認めなかったが, FIXの場合は低濃度（<1\%） でもFLTとEFPが濃度依存性に改善した。TXAを FVIII 欠乏血漿および FIX 欠乏血漿への添加により, 低濃度の TXA でさえ両欠乏血漿の線溶相を抑制し, 高濃度の TXA を添加すると, ほぼ完全に線溶反応を 抑制した．CFWAを用いることにより，凝固因子欠 乏症の病態解析, 凝固因子製剂や抗線溶薬の治療効 果などにおける凝固線溶動態を包括的に評価するこ 
とが可能と考えられた。最近，本法がFVIII製剤や Emicizumab 存在下で形成されるフィブリン構造やそ の安定性を評価することにも有用であったことを報 告した ${ }^{21)}$. また, 血友病以外の疾患領域にも T/P-GA と CFWAの両測定法が臨床的に応用可能であったこ とが最近数々報告されている ${ }^{22-24)}$.

\section{4. おわりに}

生体内では凝固と線溶は巧妙にバランスをとりな がら恒常性の維持を保っている.これまで凝固系と 線溶系で各々数多くの研究成果が得られてきたが, FVIII が両者のクロストークポイントの一つであるこ とがわかった．最近では血友病の病態が FVIII 以外 に TAFI の線溶系制御因子の関与もクローズアップ されている，さらに血漿検体を用いて両系の凝固線 溶動態を評価できる測定法も発展してきた。近い将 来, これらの新概念での制御軸を中心とした，患者 個々の重症度の予測や止血管理の方針，長期にわた る止血方針を立案することも可能になるかもしれ ない.

著者全員の利益相反（COI）の開示： 本論文発表内容に関連して開示すべき企業等との利 益相反なし.

\section{文献}

1) Hoffman M, Monroe DM 3rd: A cell-based model of hemostasis. Thromb Haemost 85: 958-965, 2001.

2) Declerck PJ: Thrombin activatable fibrinolysis inhibitor. Hamostaseologie 31: 165-166, 168-173, 2011.

3) 野上恵嗣：血友病 A の分子病態の進歩一第 VIII 因子構 造・機能からみた病態一. 日本小児血液がん学会雑誌 51: 452-458, 2014.

4) Fay PJ: Activation of factor VIII and mechanisms of cofactor action. Blood Rev 18: 1-15, 2004.

5) Nogami K, Wakabayashi H, Fay PJ: Mechanisms of factor Xa-catalyzed cleavage of the factor VIIIa A1 subunit resulting in cofactor inactivation. J Biol Chem 278: 16502-16509, 2003.

6) Nogami K, Shinozawa K, Ogiwara K, Matsumoto T, Amano K, Fukutake K, Shima M: Novel FV mutation (W1920R, FVNara) associated with serious deep vein thrombosis and more potent APC resistance relative to FVLeiden. Blood 123: 2420-2428, 2014.

7) Nogami K, Shima M, Matsumoto T, Nishiya K, Tanaka I, Yoshioka A: Mechanisms of plasmin-catalyzed inactivation of factor VIII: a crucial role for proteolytic cleavage at Arg336 responsible for plasmin-catalyzed factor VIII inactivation. J Biol Chem 282: 5287-5295, 2007.

8) Nogami K, Nishiya K, Saenko EL, Takeyama M, Tanaka I, Yoshioka A, Shima M: Identification of a plasmin-interactive site within the A2 domain of the factor VIII heavy chain. Biochim Biophys Acta 784: 753-763, 2008.

9) Nishiya K, Nogami K, Okada K, Matsuo O, Takeyama M, Ogiwara K, Shima M: Determination of a factor VIIIinteractive region within plasmin responsible for plasmincatalysed activation and inactivation of factor VIII(a). Thromb Haemost 104: 105-117, 2010.

10) Nogami K, Saenko EL, Takeyama M, Ogiwara K, Yoshioka A, Shima M: Identification of plasmin-interactive sites in the light chain of factor VIII responsible for proteolytic cleavage at Lys36. J Biol Chem 284: 6934-6945, 2009.

11) Ogiwara K, Nogami $K$, Nishiya $K$, Shima M: Plasmininduced procoagulant effects in the blood coagulation: a crucial role of coagulation factors V and VIII. Blood Coagul Fibrinolysis 21: 568-576, 2010.

12) Rijken DC, Lijnen HR: New insights into the molecular mechanisms of the fibrinolytic system. J Thromb Haemost 7: 4-13, 2009.

13) Tran HT, Sørensen B, Rea CJ Bjørnsen S, Ueland T, Pripp AH, Tjønnfjord GE, Holme PA: Tranexamic acid as adjunct therapy to bypassing agents in haemophilia A patients with inhibitors. Haemophilia 20: 369-375, 2014.

14) Janbain M, Enjolras N, Bordet JC, Bolbos R, Brevet M, Leissinger C, Dargaud Y: Hemostatic effect of tranexamic acid combined with factor VIII concentrate in prophylactic setting in severe hemophilia A: A preclinical study. J Thromb Haemost 18: 584-592, 2020.

15) Wyseure T, Cooke EJ, Declerck PJ, Behrendt N, Meijers JCM, von Drygalski A, Mosnier LO: Defective TAFI activation in hemophilia A mice is a major contributor to joint bleeding. Blood 132: 1593-1603, 2018.

16) Wyseure T, Yang T, Zhou JY, Cooke EJ, Wanko B, Olmer M, Agashe R, Morodomi Y, Behrendt N, Lotz M, Morser J, von Drygalski A, Mosnier LO: TAFI deficiency causes maladaptive vascular remodeling after hemophilic joint bleeding. JCI Insight 4: pii: 128379, 2019.

17) Semeraro F, Mancuso ME, Ammollo CT, Dirienzo L, Vitulli A, Santagostino E, Tripodi A, Colucci M: Thrombin activatable fibrinolysis inhibitor pathway alterations correlate with bleeding phenotype in patients with severe hemophilia A. J Thromb Haemost 18: 381-389, 2020.

18) Matsumoto $T$, Nogami $K$, Shima M: Simultaneous measurement of thrombin and plasmin generation to assess the interplay between coagulation and fibrinolysis. Thromb Haemost 110: 761-768, 2013.

19) Takeyama M, Nogami K, Matsumoto T, Taguchi M, Yada K, Okahashi N, Amano I, Kimura H, Shima M: Possible assessment of coagulation function and haemostasis therapy using comprehensive coagulation assays in a patient with acquired haemophilia A. Haemophilia 23: e46-e50, 2017.

20) Nogami K, Matsumoto T, Sasai K, Ogiwara K, Arai N, Shima M: A novel simultaneous clot-fibrinolysis waveform analysis for assessing fibrin formation and clot lysis in haemorrhagic disorders. Br J Haematol 187: 518-529, 2019. 
21) Shimonishi N, Nogami $K$, Ogiwara $K$, Matsumoto $T$, Nakazawa F, Soeda T, Hirata M, Arai N, Shima M: Emicizumab improves the stability and structure of fibrin clot derived from factor VIII-deficient plasma, similar to the addition of factor VIII. Haemophilia. Mar 11. doi: 10.1111/ hae.13961, 2020.

22) Yoshizawa H, Nogami K, Matsumoto T, Tsujii N, Sakai T, Takase T, Tanaka I, Shima M: Dynamic evaluation of hemostasis in the acute phase of Kawasaki disease using comprehensive coagulation functional assays. Thromb Res 174: 76-83, 2019.
23) Ishihara $T$, Nogami $K$, Ochi $S$, Ishida $T$, Kosaka $Y$, Sawada $A$, Inoue $\mathrm{M}$, Osone $\mathrm{S}$, Imamura $\mathrm{T}$, Hosoi $\mathrm{H}$, Shima $\mathrm{M}$ : Disordered hemostasis associated with severely depressed fibrinolysis demonstrated using a simultaneous thrombin and plasmin generation assay during L-asparaginase induction therapy in pediatric acute lymphoblastic leukemia. Pediatr Blood Cancer 67: e28016, 2020.

24) Ishihara $T$, Nogami $K$, Takeshita $Y$, Ochi S, Shima M: Fibrinolytic abnormality associated with progression of pediatric solid tumor. Pediatr Int 60: 540-546, 2018. 